\title{
THE STUDY OF DECORATIVE ELEMENTS OF SIAMIAN GORJI HOUSE
}

\author{
A. Salehi ${ }^{1, *}$, M. N. Goljah ${ }^{2}$, A. S. Baladehi ${ }^{3}$ \\ ${ }^{1}$ Department of Art, Shahed University, Tehran, Iran \\ ${ }^{2}$ Imam Hussein University, Iran \\ ${ }^{3}$ Department of Architecture, Applied Science University of Behshahr, Iran
}

Published online: 08 August 2017

\begin{abstract}
Among different architectural artifacts developed in history of architecture in Iran most of which are based on traditional architecture, house is regarded as most significant architectural artifact since it is one of the earliest architectural constructions and it is directly association with security and calmness of human beings as well as regional ecosystem. Qajar era could be regarded as period of innovations and significant changes of art and architecture of Iran. Houses are among architectural wonders and some of the most significant constructions of this period of time since lots of attention was given to decorations and especially drawings. Among significant factors contributing to majesty of architecture of Qajar era, one could point to decorations of buildings. Increasing associations and exchanges with West and introduction of modern sciences to Iran in this era was followed by distinctive influences on architecture and more especially, to decorations of buildings. In the present study, results of objective observations, field studies and library studies of decorative elements of Siamian Gorji House, one of the historical houses constructed during Qajar reign in Behshahr Town, are detailed in a descriptive and analytical manner. Therefore, the present study aims to identify decorative elements used in different parts of Siamian Gorji House and review types and styles of these elements. The results of present study mostly deal with influence of decorative elements of Qajar era on such houses.
\end{abstract}

Author Correspondence, e-mail: author@gmail.com

doi: http://dx.doi.org/10.4314/jfas.v9i2s.844 
Keywords: Decorative Elements, Qajar, House, Mazandaran, Behshahr, Siamian Gorji.

\section{INTRODUCTION}

If one presumes a body and a soul for architecture, decorations and drawings act like a soul that fit the body of structures in itself. Decorations are among significant architectural elements that exclude dryness and soullessness from façade of a building and assign it distinctive identity and characteristics. Architectural decorations add to value of a building, integrates its different elements and enhance efficiency of architectural space. Based on decorations of different constructions, one could determine whether decorations play a fundamental role in development and persistence of architectural objective or not. Study of these decorations suggest their progress and perfection in different periods of time. Analysis of integrity of façade and body of historical buildings, especially houses, is a way of getting to know perceptions of last-generation architects and to attain a way to use in architectural design of Iran of present era. Decorations and drawings used in Iranian architecture are highly diverse and they have been used in different historical eras. Siamian Gorji House is among major buildings of Qajar era. It is located in Behshahr Town and it has significant and numerous decorations. The present study aims to study architectural decorations used in Siamian Gorji House and determine type and style of these decorations. The present study is descriptive-analytical in its approach and it is mostly premised on field studies.

Architecture of Qajar Era

The architecture of Qajar era could be divided into two general period. The first period is from early reign of Agha Mohammad Khan to end of Mohammad Shah's reign. In this period, approach to architecture is still inward and premised on perfection of Isfahan-specific architecture. The Shrine of Masome (PBUH) in Qom and Sultani Mosque are major instances of this type of architecture. The second period is from early years of Naser Aldin Shah's reign to the end of Qajar Dynasty. In this period, travels of Naser Aldin Shah, sending some Iranian students to Europe for further training and influence of European civilization on ruling board and elites led to development of a new architectural style which was a combination of local architecture and western architecture.

The architectural art of Qajar era is regarded as highly weak in comparison with Safavid era, especially in terms of buildings. Solely during long reign of Naser Aldin Shah, influence of western art led to significant progress of art and architectures as well as exquisite industries such 
as stucco, mirror decorations and tiling. Higher association between Iran and West, let to meticulous combination of distinct elements of Iranian architecture with certain elements of western civilization and development of artistically pleasing works. However, architecture of Qajar era promoted old Iranian principles and algorithms but offered certain spatial innovations. However, it seems that if we evaluate architectural works from perspective of space and pay attention to spatial innovations in architecture, architecture of Qajar era will find its true value. In this case, it could be considered as superior to architecture of previous Safavid and Zandieh eras because there are higher spatial innovations, higher spatial innovations, and more modern spaces in architecture of Qajar era. In sum, if evolution of architecture is approached in terms of clarity and lightness of spaces the architecture of this era could be conceived as evolution step of old Iranian architecture. However, when architecture of this era is approach from other aspects such as size, proportions, size and decorations, architecture of Qajar era is placed in inferior place than previous eras, especially Safavid era (Mahmoodi, 2013: 13).

Significance of Decorations of Qajar Era

Because of opposition between tradition and modernity in Iran, Qajar era could be regarded as significant. In this period, significant changes occurred in lifestyle and values of Iranians, especially their architecture. Ignorance of attention to new sciences in early Qajar era due to exclusive attention to religious and religious studies in Safavid era, ignorance of natural sciences, mathematics, and modern industries as well as increasing association between Iran and West are among major events of this era. Development of modernity in Europe, technological developments, inventions of steam engine followed by revolutions are major influences on social life of Iranians as well as architectural buildings.

Decorations of Architecture of Qajar Era

During long reign of Naser Al-din Shah, influence of western architecture led to significant progress of relevant arts such as stucco, mirror and tile decorations (Purbizhani, 2010: 72). The architecture of Qajar era is significant in terms of commitment to follow earlier Iranian traditions and vivid influence of western civilization. Historical progress of these two characteristics are also vivid in traditional decorations. Abstract forms such as western flowers are primary decorative drawings of Qajar era which are more frequently seen in stucco decorations of the time. Stucco decorations developed significantly during Qajar era. Because of kings' travels to 
Europe, imitations were made of stucco decoration art of Europe. This is most vivid in column heads, and roofing of palaces (Gholizadeh, 2009: 480).

Decorations are inherent part of Iranian architecture. In traditional Iranian architecture, architects believed that decoration of each building should be aligned with identity, body and application of the building as well as urban fabric (Mahmoodi, 2010: 32).

In this regard, brick is one of the most significant material in Iranian architecture which has been used from a long time ago for covering facades (Sultanzadeh, 1994: 95). Traditional architecture has used bricks more than any other material because it is stronger and easier to use. In addition, bricks could be used molded for different sizes and used in any directions to develop complicated structures and interesting facades. In Iranian architectural decorations, bricks were used for developing beautiful facades (Navai \& Ghasemi, 2011: 48).

\section{Introduction of Siamian Gorji House in Behshahr}

Behshahr Town is located in the east of Mazandaran Province. The province is limited in north to Caspian Sea, in south to Alborz Mountain Chain and Semnan Province, in east to Golestan Province, and in west to Neka Town.

Siamian Gorji House is located in southern side of Alborz Mountain Chain. More precisely, it is located in south of Gorji Mahale Village. The house is rectangular $\left(11.5 \times 14.5 \mathrm{~m}^{2}\right)$. The building has three floors made up of bricks, plaster, limestone, wood and clay roof. The underground is developed like a crypt and the house has a square-shaped pool $\left(1.5 \times 1.5 \mathrm{~m}^{2}\right)$ as well as numerous niches at different sides of interior walls. The reason behind constructing the pool in the yard was maintaining humidity. The middle floor of the building has a central room and a terrace with arch-shaped niches in four sides. In northern and southern side of this floor, door tops have colored glasses in their skylight sections. In addition, there is an entry in eastern as well as western side of the building. The top floor of the building has a similar central room as well as tripartite doors at four side of the building.

The total are of this building is about 18 hectares. The trees are of diverse kinds. One of the most significant characteristics of this building is that no metal (not even a metal nail) has been used in its construction. Strabo, a Greek philosopher, visited the building and referred to it as one of the strongest buildings in the world.

Small dent-like decorations and drawings, geometric patterns (in rhombic shape), and cedars as well as tetramerous stars, strip layout and coloring are among decorations used in this building. 
Around the building, rows of rocks were covered by bricks and straw. Architecture of this building is a vivid instance of Georgian visual arts and it is modelled on Georgian architecture of USSR era. The design and geometric patterns used symbolize Georgian gods.

The construction of this building lasted 7 years. Development of the building ended in the same year that Allahverdi Khan, Khajoo and Siosepol bridges were made. The building was made by Haji Ismail Khan and the building was used for seasonal residence and not for permanent living. In regard to architectural form and decorations and materials, the building could be regarded as an instance of architecture of Qajar era. The pictures of this building in Louvre Museum, the Roman Museum and one of the oldest churches in Tbilisi (Georgia) were taken by Strabo, a Greek philosopher (Central Office of Cultural Heritage of Mazandaran, 2003).

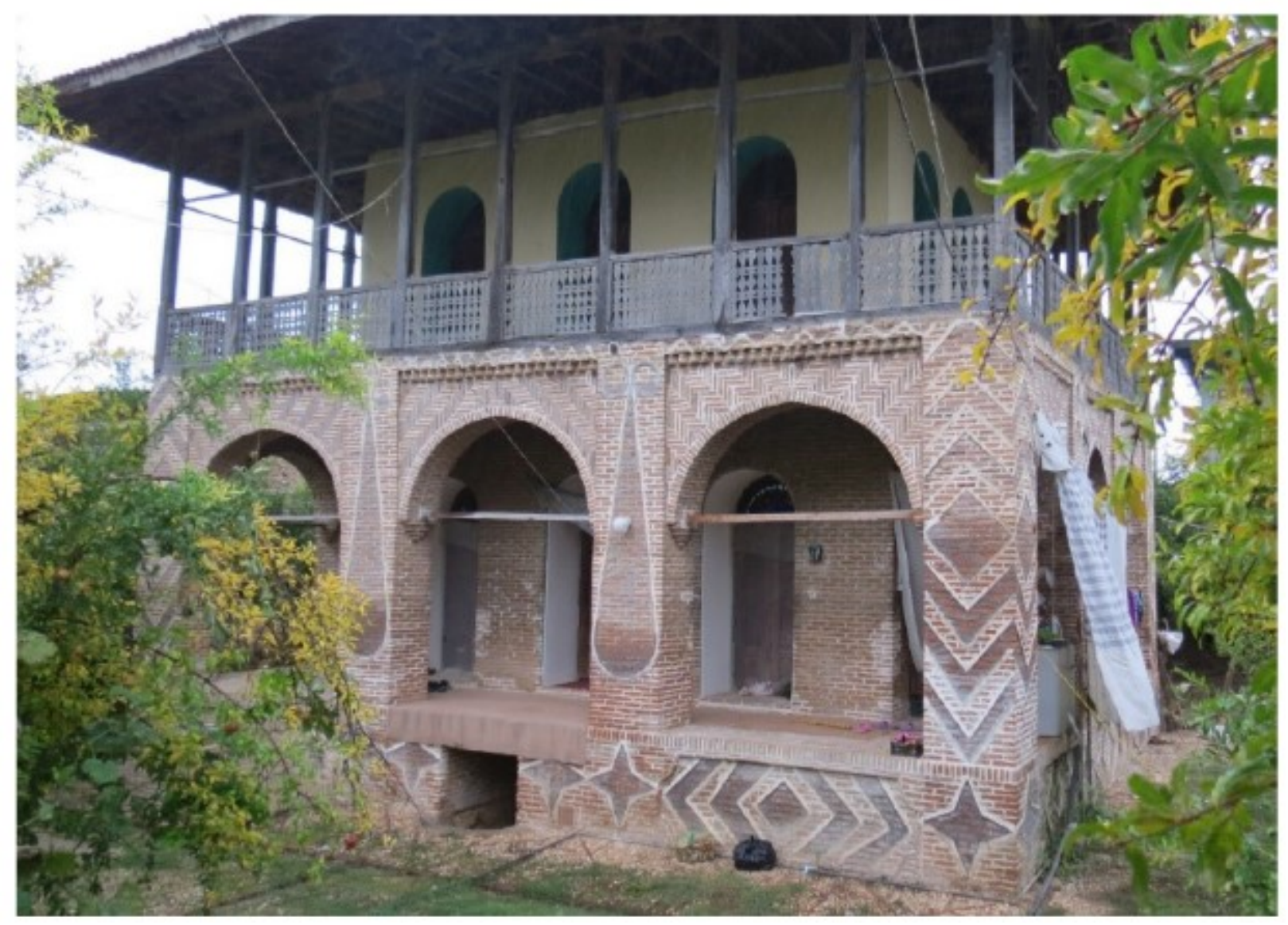

Fig.1. Samian Gorji House.

In the following, decorations and drawings used in Samian Building will be detailed summarily.

Type of Decorations in Samian Gorji House

In each period of time, art represents thought, belief and customs or collectively the culture of a tribe or a nation. In fact, art of a tribe originates from worldview of the nation. A cursory review 
of buildings of Islamic era (e.g. a house) suggests that houses in different Islamic regions have common characteristics in their interior and exterior view. Samian Gorji House is not an exception to this. In Samian Gorji House, different decorative elements were used for beautification of interior and face of the building. However, decorations of the face are more in number. Among these decorations, one could point to decorative patterns in the building façade, artistic arrangement of bricks and use of wooden net-like doors all of which will be discussed in detail later.

\section{Decorations of Siamian Gorji House}

One of the distinctive characteristics of a house is its decorations. Decorations are essential part of Islamic architecture since they play a valuable role in realization of objectives of Islamic architecture and persistence of such architecture (Makinezhad, 2008: 17).

Bricks: Almost all houses of Qajar era are made of similar materials such as wood, simple and colored glass, square brick and mud. Bricks play a significant role in developing pattern and drawings of these houses. Higher of bricks for construction and decoration of houses than stone is witnesses in mid centuries of Islamic civilization. The origin, significance and evolution of this style of decorative brick layout is a little ambiguous because oldest samples of brick layout are among its perfect instances too. This means that with exception of dome, other parts of buildings had dual applications. All of the surfaces were decorated and interesting patterns were used in architectural elements such as walls and towers. In consequent centuries, use of bricks was not solely a decorative technique. Application of bricks turned into a major architecture technique and bricks were used more frequently. Variation of brick layout was not done to emphasize on major lines of the building but to distringuish decorative surfaces from each other (Hill and Grabber, 2007: 102).

Heated bricks made up of soil is miraculous in terms of arousing our feelings because bricks signify civilizations, feelings, cultures and tastes of different nations. Soil symbolizes persistence, maintenance, continuity, and stability. Soil is one of the most important elements since its mixture with other elements contribute to stability and strength of a building (Naima, 1998: 14).

The use of brick layout along with other materials in façade of buildings of Qajar era is observed frequently. The walls of Siamian Gorji House had a thickness ranging from 60 to $80 \mathrm{~cm}$ since mud- and limestone-made materials dried soon in comparison with cement and sand. Usually, bricks of Qajar era were square in shape and their typical size was $17 \times 17 \mathrm{~cm}^{2}$. 
Probably, the most frequently used decoration in historical building which creates distinct patterns and decorations is strip layout between bricks. The strips were used in façade of this building. Combined with ash in a lime mortar, the strips were used in external surfaces of brick walls. Apart from their mystery, these patterns are highly diverse and they impose a gray color tone on the building façade. Although the gray color is neutral and it does not initially fit the building, the use of such a neutral color is effective upon façade of buildings. In northern provinces of Iran, especially provinces that are adjacent to Caspian Sea, most days were cloudy and gray-colored, the gray color used in between-brick strip layout symbolizes an always cloudy sky (Pirzad, 2011: 8).

\section{Arcade}

The entry into the building is arched structure at the top of which small dent-shaped decorations are seen. The arcades of Qajar buildings were simple structures (simple crescent shape) with Roman design. Arcades were simple arched structures with Roman layout on walls of yard and above door or window. For beauty of façade of buildings, bricks were arranged in both horizontal and vertical orders (upward or downward arrow shapes) as if they were strewn together. In simple wall layout, mortar was uniformly used to develop an asymmetrical shape. The size of bricks contributed to this issue. The size of bricks ranged from 1.5 to $2 \mathrm{~cm}$, they were $5 \mathrm{~cm}$ in width and $1.5 \mathrm{~m}$ in length. 


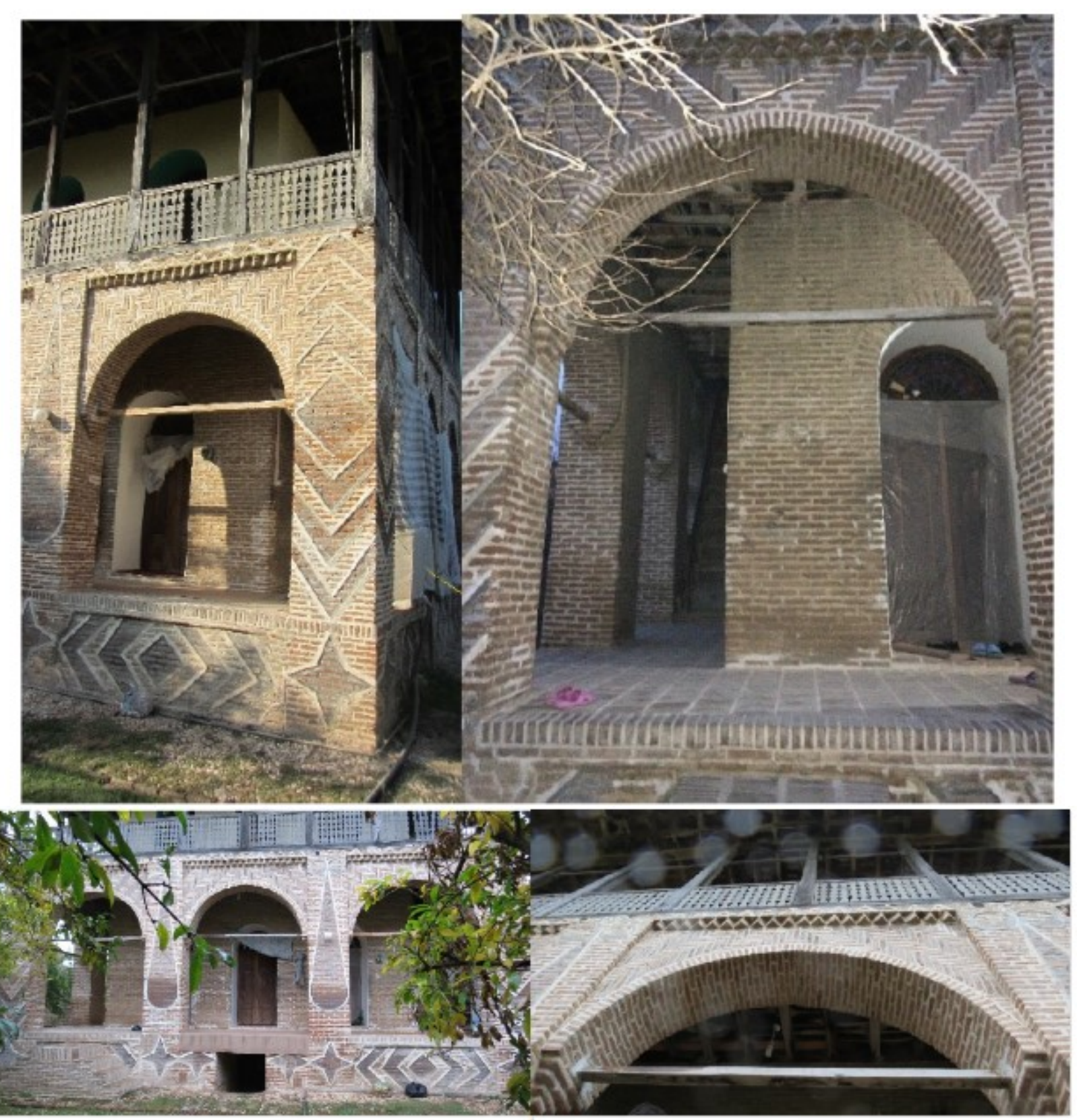

Fig.2. Arcades of Siamian Gorji House

Decorative Patterns

Unique forms with distinct meanings were used in construction of façades of most of historical buildings of Qajar era. In addition to assigning more beauty to the buildings, the forms have distinctive characteristics too. Certain symbols (e.g. sun, moon, plants, animals and legendary birds) used in different buildings and religious locations signify cultural background of using these symbols in local arts of the region. One of the familiar and beautiful symbols used in old 
buildings such as Siamian House of Behshahr City are the symbol of cedar and lion-and-lion; these symbols were used in brick façade of buildings and strip layout between bricks.

The symbol of cedar is an eye-catching sight for any visitor; in addition, cedar symbolizes freedom, permanent live, truthfulness, and resistance. In ancient legends, cedar is devoted to sun and therefore at the top of cedar symbol used in old buildings, there is a sign of sun. The cedar symbol represents protection of local and Islamic values of architecture as well as notions of pride, righteousness, greenness and stability (Salehi Baladehi, 2013: 10).

The local people of Mazandaran consider freedom as highly significant notion. That is why, they celebrated the notion in their culture and traditions and use their works to represent freedom. Therefore, old beliefs and conceptions as well as ancient customs are considered in adding the symbol of "cedar" to Siamian House of Behshahr City. The cedar trees on exterior of Siamian House convey the abstract notions of power, loyalty, resistance, peace, friendship, seeking freedom and living in other world. From viewpoint of people of Mazandaran, tree is regarded as source of goodness and greenness.

Architect of the house combined strip layout and brick layout in top part of external space of Siamian House so as to draw the attention of visitors to top of cedar tree. Because of its distinct form, cedar tree points to the sky. Rise to the heaven is reflected in depiction of cedar tree so as to convey its function as a symbol of freedom and divinity. In addition, distinct representation of the tree invites the audience to the divinity. For long, cedar tree has been considered as a trustworthy symbol. That is why it is frequently worked out on historical house of Mazandaran Province.

Combined representation of sun and lion (i.e. half-risen sun on back of a lion) conveyed different meanings in different periods before and after Islam. In Islamic era, apart from astronpmic denotation the symbol has astronomic denotation as well as religious signification. In addition, it has been charged with some political implications and certain modifications were made in representation of the symbol. The religious conception of the combined symbol of sun and lion in Islamic art emerged since late years of Seljuk reign as it was used to represent Shia. Because of bias of Seljuks for advocates of Shia, the symbol was used in shrines of princes and Shiite places as well as consequent Shiite governments. Here, sun is regarded as symbol of Prophet Mohammad (PBuH) and lion was considered to symbolize Imam Ali (BBuH) (Khazai, 2003: 38). During reign of Seljuk Dynasty, the symbol played a significant role. During this era, sun was 
shown as fully rising above the lion. However, going from Seljuk to Pahlavi era the sun was again represented as half-risen above the sun. This change was attributed to artists' hurry (History of Sun and Lion Symbol, 1931: 588).

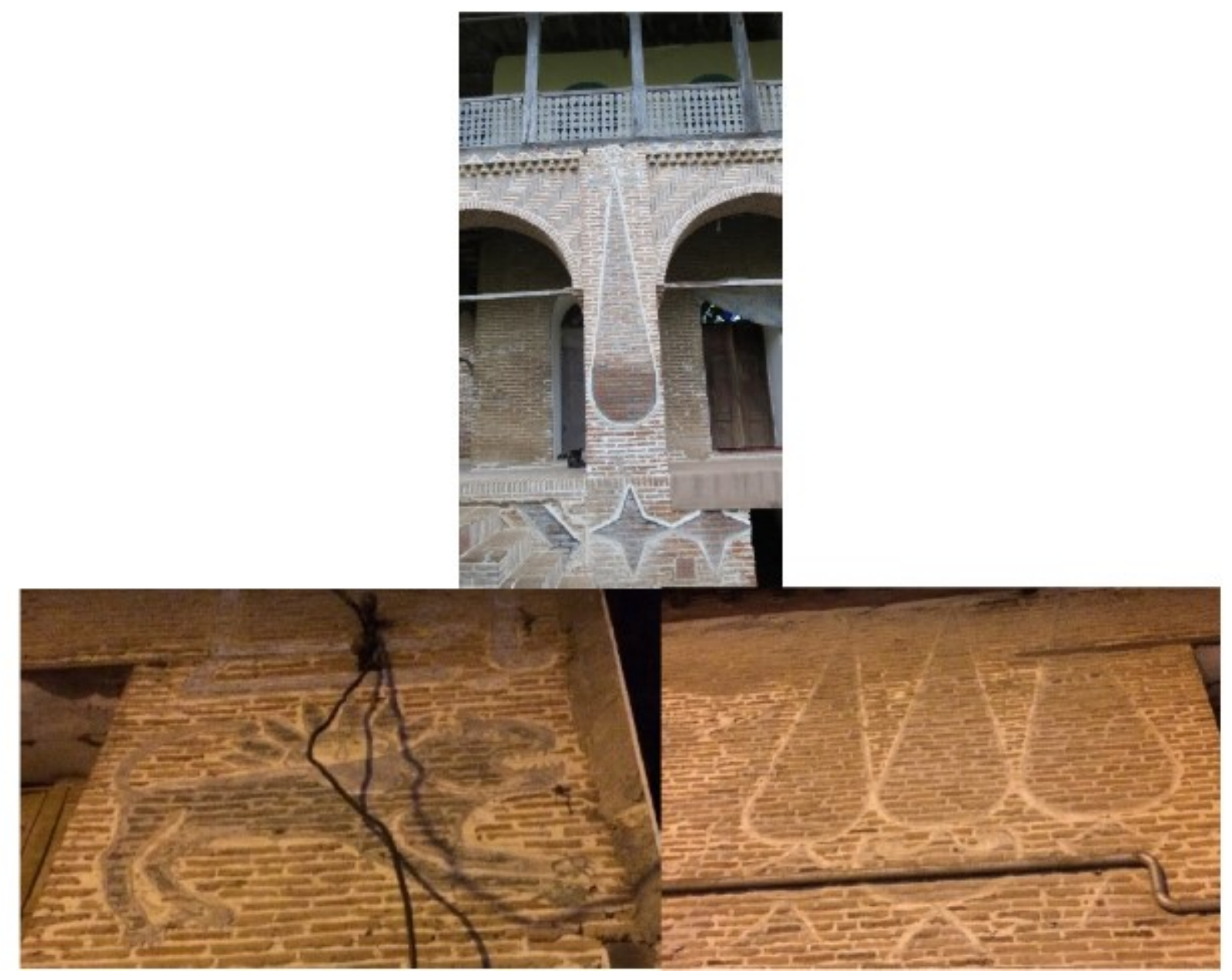

Fig.3. Decorations used on wall of the wall.

In addition to developing brick layout in the shape of small dents, cedar-shaped decorations, squares, rhombuses and four-leave flowers, other decorations were made by laying out strips of plaster and color (Central Office of Cultural Heritage of Mazandaran, 2003: 17). 


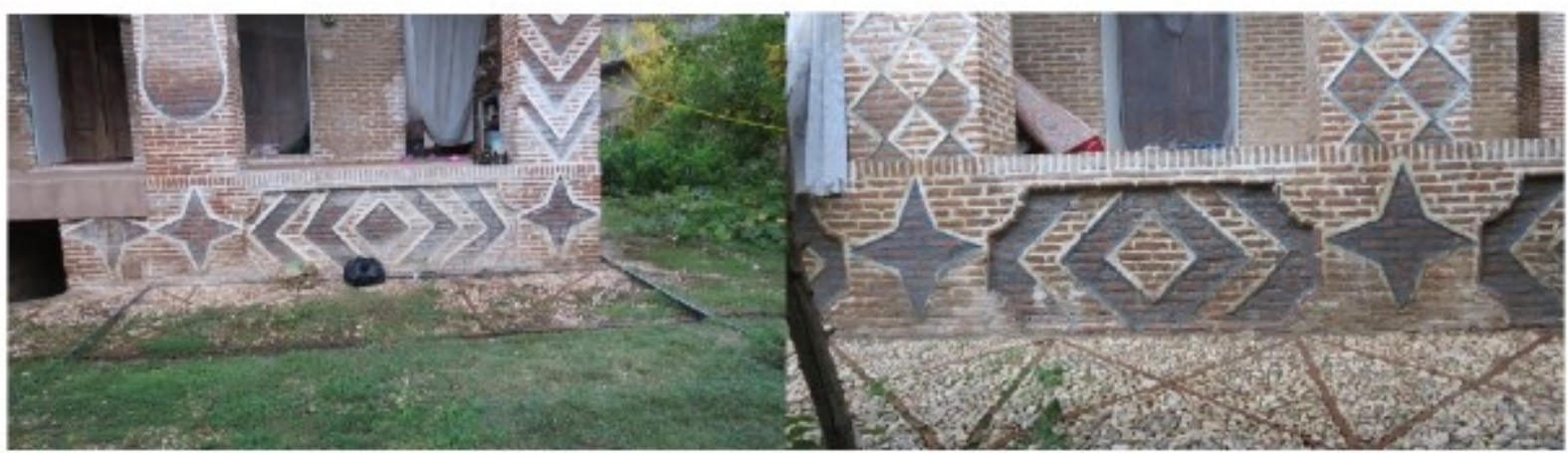

Fig.4. Decorative shapes.

Colored Glasses

Among other characteristics of this building, one could point to use of colored glasses at the top of the doors. In different angles of this building, wooden doors with decorative colored glasses at their top add to beauty of the building. The windows were used in main angle or interiors of the yard for beautification of the building. These windows are artistically significant too. All of doors and windows have crescent shape and they play an influential role in façade and beauty of the building. Doors and skylights in houses of Qajar era usually have $2.50 \mathrm{~m}$ height and at the top of their frames, there are crescent-shaped frames decorated with colored glasses. Of course, use of colored glasses and net-like structures depended on financial condition of house owner. Some doors and windows of buildings constructed during Qajar era were decorated with simple glasses. In addition, net-like decorations were sometimes substituted by simple division of crescentshaped section into three or four parts.

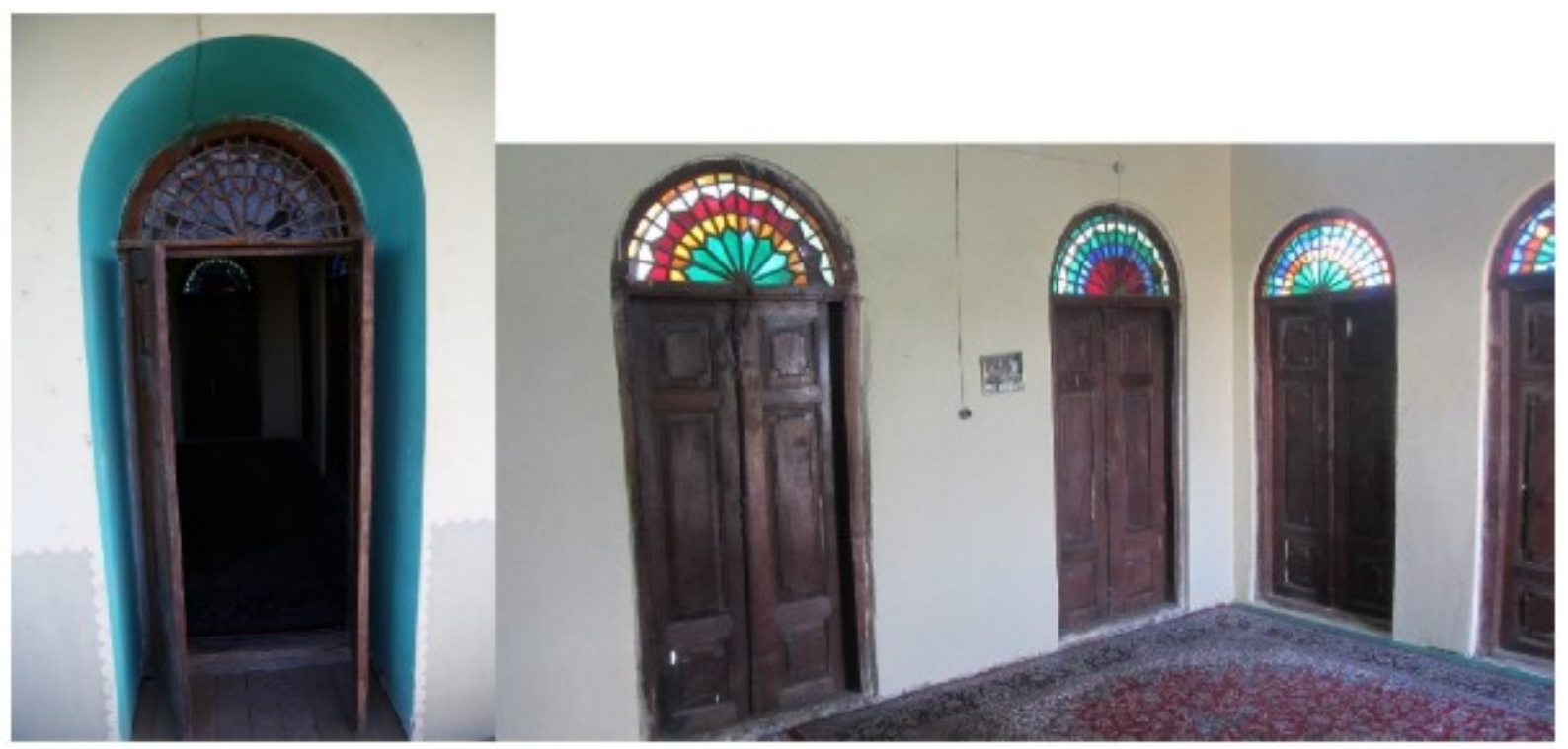

Fig.5. Different entries with wooden decorations and semi-circular curves at top 


\section{Wooden Lion Heads}

The decorative elements were always used for roofs of houses of Qajar era. Almost all buildings of Qajar era have these decorations. These elements add to beauty of buildings and have structural function too. In addition to enhancing structural resistance against water and protection of walls, the reduced weight of the roof significantly. The lion heads also acted as spout and they prevented rainwater from penetration into second floor of the building. In addition, these lion heads act as shadow and consequently, they reduce direct exposure of interior of a building to direct radiation of sun.

To make these lion heads, three pieces of wood with different lengths were used. The wood pieces were arranged in a distinctive manner and shape of lion's head was carved out of them. Using three pieces of wood to make a lion head was done to add to strength of finished object because a single piece of wood shows less strength and it is more prone to fractures under weight of snow or rain.

Sometimes, carving out pieces of wooden beams was accompanied by shaping up peripheral edges of those beams too. On some of the beams, verses of Quran were carved out so as ask for divine protection of building and its residents.

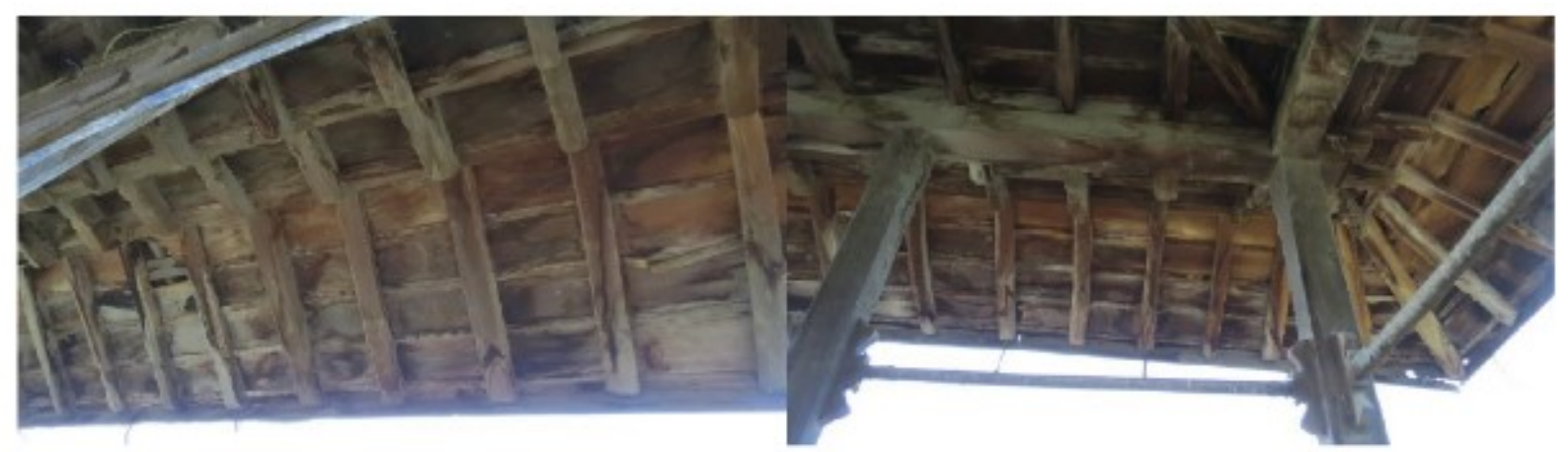

Fig.6. Wooden lion heads.

Roof

Inclined covers were one of the significant characteristics as well as elements of buildings constructed in northern Iran. One of the common materials for covering rooftops is tile. In the past, tiles were used for covering the roofs of significant buildings such as mosques, shrines, houses and public bathhouses. The tiles were usually 30 to $40 \mathrm{~cm}$ long and 12 to $15 \mathrm{~cm}$ wide and they were used for covering rooftops of buildings of Qajar era. In order to make the tiles resistant against wind, water and thunderstorms, the tiles were installed on rooftops at the angle of 50 
degrees. The front side of rooftops were fixed with a mixed limestone and mud mortar so that it can resist against wind. The top of each slope was also fixed with the same type of mortar.

Because of climatic condition of the region and use of certain materials such as wood and tiles for the rooftop, growth of moss and grass on rooftop cause some problems for top floors. To address the problem, limestone was used to fill in the gaps and spaces between inclined surfaces. In this case, growth of moss was prevented.

Yard Covering

Depending on location, significance and use of each space, coverings of floors of a building were different from one another. Some uses of these coverings are noteworthy such as covering the space, representing value, significance and difference of space, delimiting private, semi-private and public spaces of houses, beauty, cleanness, regulation of movements and users, ease of mind and protection of privacy along with easy use of spaces.

All of these applications are realized through proper selection of materials, techniques of construction, drawings, and color of matterials.

Most of floor coverings used in houses of Qajar era were composed of square or rhombic bricks and gaps between them were filled with strips of mortar. In Siamian House, this type of bricks was used for stairs. At the yard floor of Siamian House, different designs and patterns have been used for beautification of the space. The shapes are surrounded with bricks and inside the shapes, large stone pieces are used. 


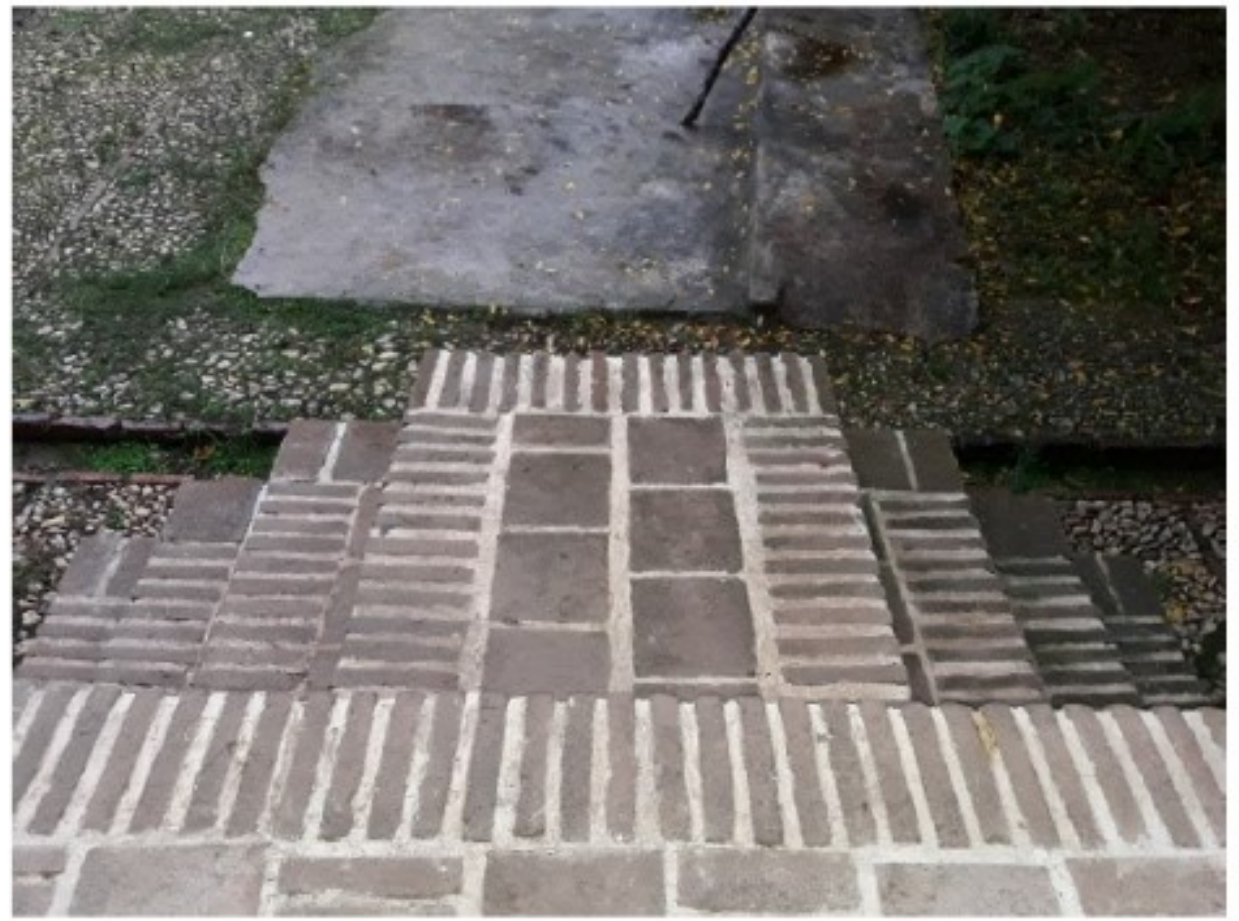

Fig.7. Arrangement of bricks for a two-sided stair at entry of the building

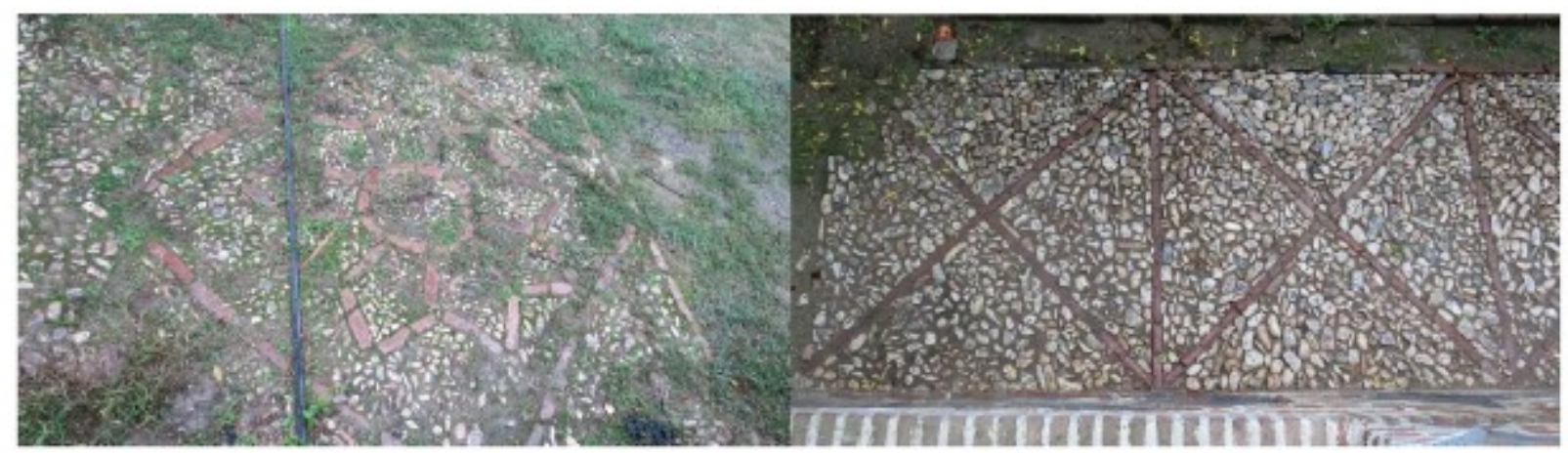

Fig.8. Decoration of yard covering

In addition, there is a pool in the middle of the yard which surrounds the building by a small artificial brook. In the case of using the pool, water flows all over the yard and then, it pours into a pool-like hole at the back of the building. 


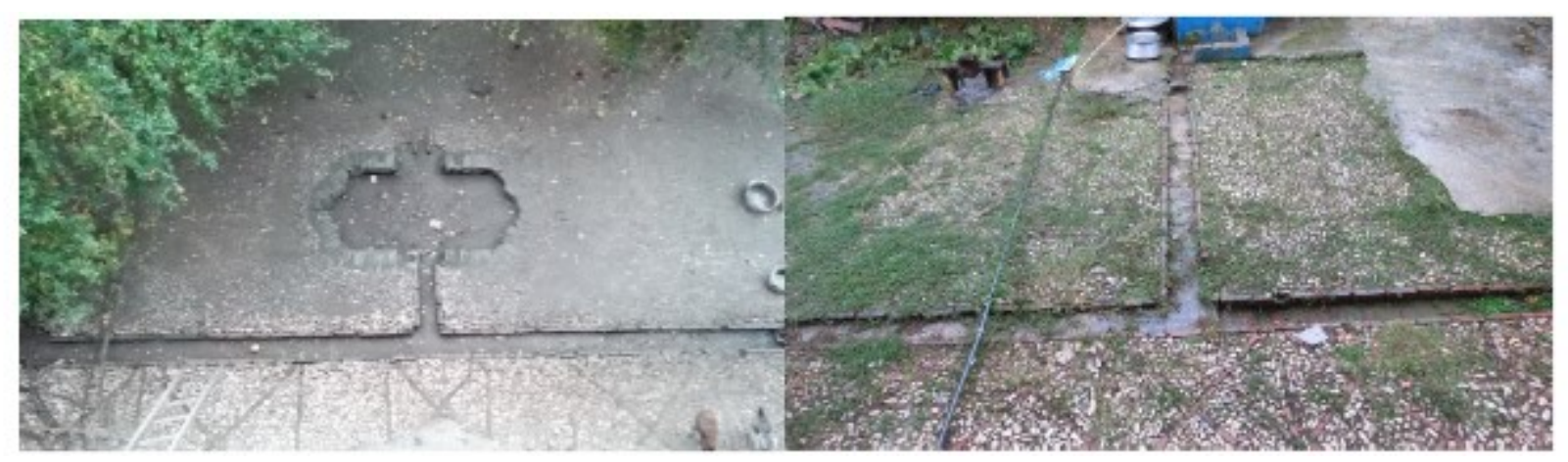

Fig.9. Northern and southern view of the pool

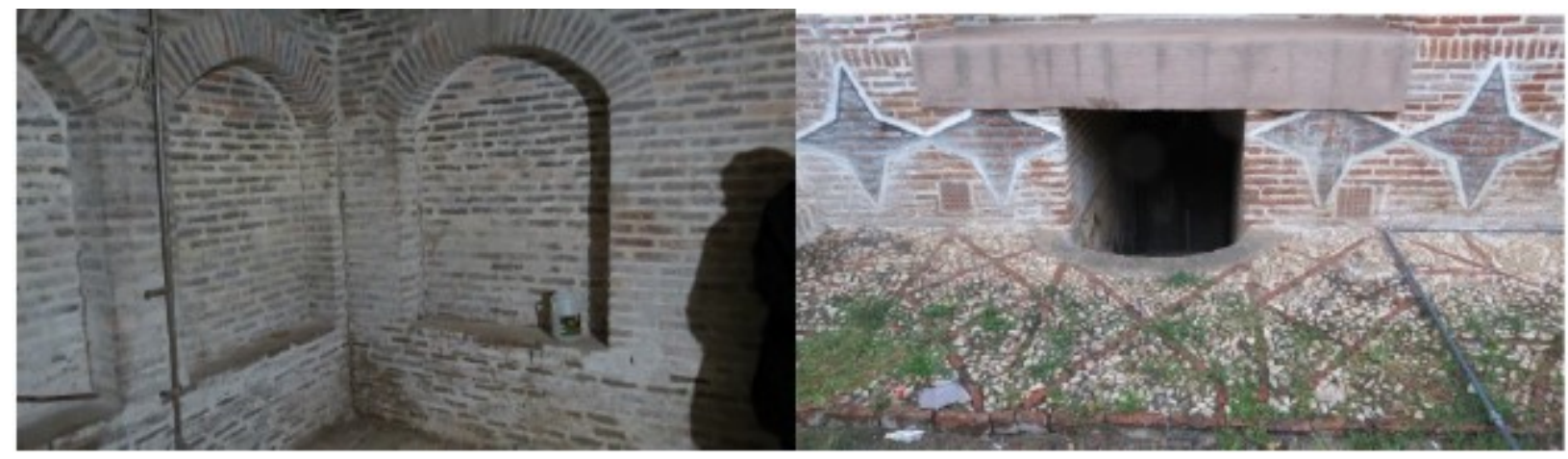

Fig.10. Entry to the basement

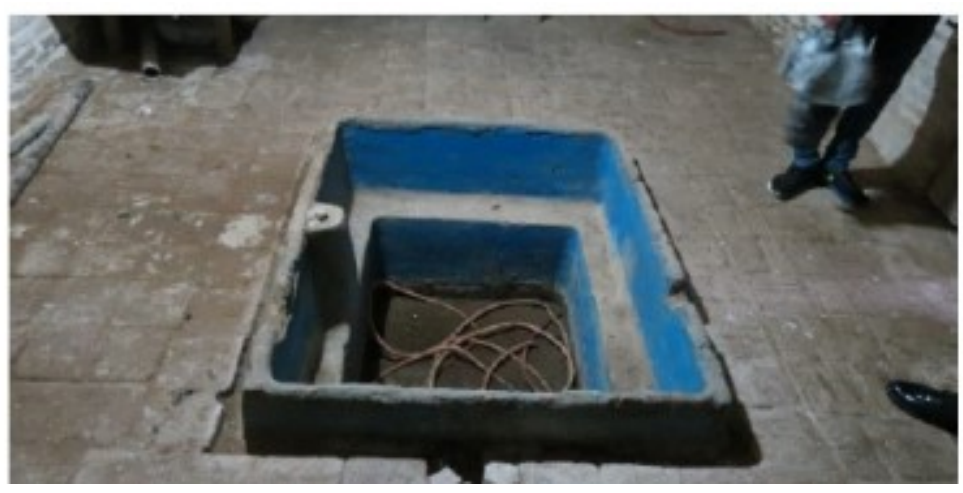

Fig.11. Pool at basement

\section{CONCLUSION}

Essentially, architecture deals with something more than material structure or aesthetic shape of a building. Architecture is a humanistic phenomenon and it is inevitably influenced by the community. Religion, tradition, beliefs, security problems and worldview of people influence architecture of every region and architecture of each period is different from others since it aims 
to appeal to the soul of the man of the time and to provide for his ease of mind. In pre- and postIslamic Iranian architecture, decorations play a significant role. Basically, essentially diverse decorations are inevitable part of architecture of a building, especially during Qajar era when decoration-based aesthetics is emphasized.

In Iranian architecture, decorations and decorative themes play a highly significant role in communication of notions and their implications. In other words, decorations contribute to cultural identify of human and community. Thorough understanding of characteristics of decorations of buildings belonging to Qajar era is impossible without attention to primary factors contributing to development of such buildings (e.g. materials, instruments and techniques). This requires further study. In residential buildings of Qajar era (especially during late years of Qajar rule), emphasis on exterior gradually substituted for emphasis of interior of residential buildings as practiced before. In this period, art of decoration drew upon beautiful architectural styles of traditional houses of Iran so as to develop a distinctive mix of artistic development. As a residential architecture, Siamian Gorji House is not an exception to this development. In this house, diverse drawings were executed by different techniques and each design conveys a distinctive message and implication that matches vision and viewpoint of the building users. Among significant characteristics of major decorations of these buildings, one could point to the association between shape and form of the building so that brick layout decorations match general shape of the building so significantly that there is a unity between theme and design of a project. With help of decorative aspect of brick layout, the architect emphasized the general map of the building.

\section{REFERENCES}

Guide of Historical-Cultural Works of Mazandaran Province. (2013).

Hill, D \& Grabber, O. (2007). Architecture and Islamic decorations, In Vahdati, M. (Trans.), Scientific and Cultural Press: Tehran.

History of Sun and Lion. (1946). Armaghan Journal, 11 (118).

Khazai, M. (2013). The role of lion in Islamic art, Journal of Visual Arts, 17.

Mahmoodi, M \& Chaeede, A. (2010). The use of mathematics for architecture in Iran (Study of role of geometric proportions in decorations of entry of houses located in old fabric of Dezful City), Tehran, Monthly of Science and Techniques, 129. 
Mahmoodi, M \& Sayaf, F. (2013). The study of the role of traditional architectural drawings in façade of residential houses of Qajar era to the moment, National Conference of Architecture, Restoration, Civil Development and Sustainable Environment.

Makinezhad, M. (2008). History of art in the era of Islamic architectural decorations, Samt Press. Moqim Purbizhani, T. (2010). Mirror decorations in architecture of Qajar era (A cursory look at history of mirror decorations and their use in history of art in Iran), Journal of Mahe-Honar, Tehran, 140.

Naima, A. (1998). Dezful: City of bricks, National Cultural Heritage Organization, Tehran.

Navai, K \& Haji Qasemi, K. (2011). Tile and imagination: Explication of Islamic architecture of Iran, Tehran University; Tehran.

Pirzan, A. (2011). The study of artistic values of architectural decorations in historical houses of Qajar era in central areas of Mazandaran, Tenth Conference of Protection and Restoration of Historical-Cultural Objects and Architectural Decorations, Tehran.

Qolinezhad, M. (2009). Architectural decorations in art history of Iran of Islamic era, Tehran: Samt Press.

Salehi Baladehi, A \& Salehi Baladehi, Atena. (2013). The study of cedar symbol in historical houses of Mazandaran (A case study on Kardeli House of Behshahr Town), First National Conference of Geography, Civil Development and Sustainable Development.

\section{How to cite this article:}

Salehi A, Goljah M N, Baladehi A S. The study of decorative elements of siamian gorji house. J. Fundam. Appl. Sci., 2017, 9(2S), 1273-1289. 